\title{
Jentink's duiker in Sierra Leone: evidence from the Freetown Peninsula
}

\author{
Glyn Davies and Bastian Birkenhäger
}

Jentink's duiker, Africa's rarest duiker, was reported to be common in Sierra Leone at the turn of the century, but subsequent investigations failed to find evidence of the animal's presence. In 1988, as part of a faunal survey organized by the Conservation Society of Sierra Leone, the authors discovered that the duiker definitely occurred there and that some had been recently killed. Although this finding extends the known range of the species, the duiker is rare and remains poorly known. There were recommendations to protect the forests of the Freetown Peninsula even before the presence of the duiker was confirmed and these are now reinforced.

\section{Introduction}

Jentink's duiker Cephalophus jentinki is one of the largest duikers in Africa and is certainly the rarest. It is found only in the western part of the Upper Guinean forest block, which stretches from eastern Sierra Leone, through Liberia and southern Ivory Coast into southwest Ghana. Many rare mammals and birds are endemic to this forest block, and there are even distinct subspecies on either side of a faunal boundary in south-west Ivory Coast. Two rare duikers unique to forest west of this boundary are the zebra duiker $C$. zebra and Jentink's duiker.
Confirmed reports of Jentink's duiker exist from several parts of Liberia (Kuhn, 1965), and from south-west Ivory Coast (Roth and Merz, 1986). There is a remarkable report stating that Jentink's duiker was very common in Sierra Leone at the turn of this century (Stanley, 1928), but subsequent investigators found no evidence of the species (Jones, 1960). Recently there have only been unconfirmed reports that Jentink's duiker occurs in the Gola Forest Reserves (Davies, 1987) and in the hills of the Freetown Peninsula (J. Waugh, pers. comm.)

As part of the Conservation Society of Sierra Leone's faunal survey, we conducted interviews with hunters in the southern part of the Freetown

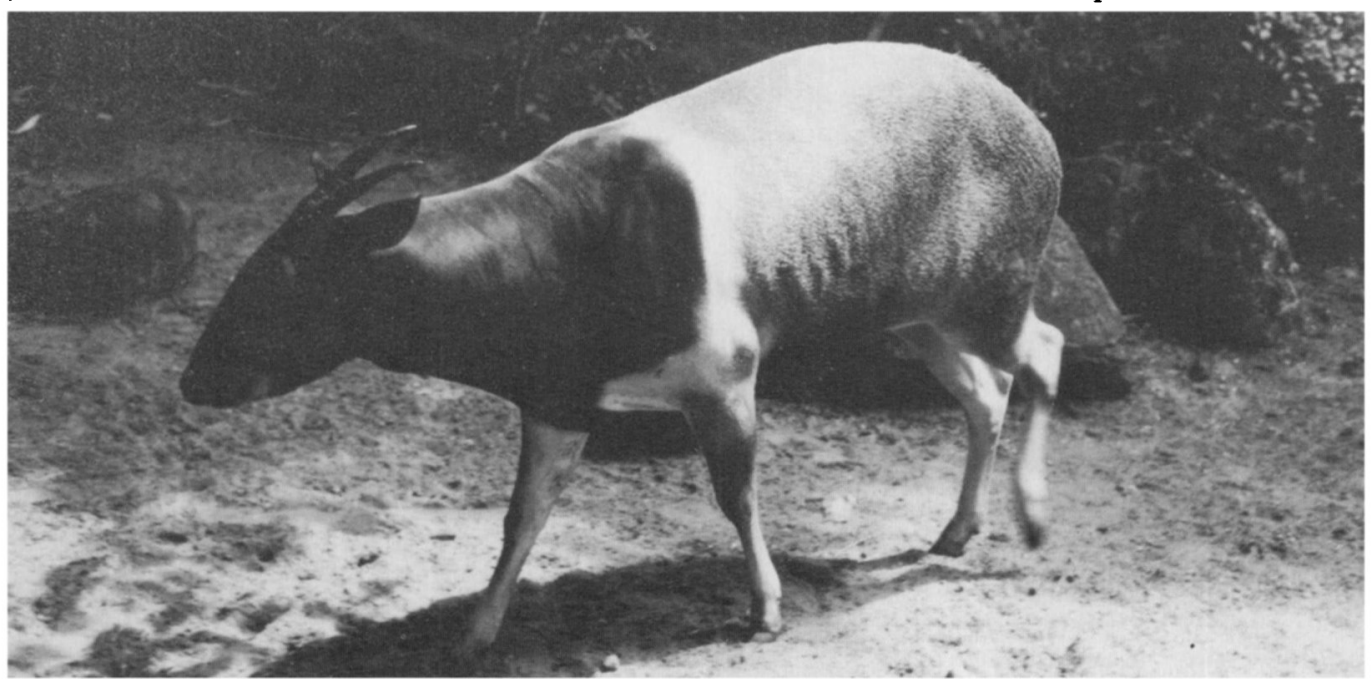

Jentink's duiker (Glyn Davies). 




Figure 1. Freetown Peninsula showing the location of Jentink's duiker kills and sightings. Inset map shows other areas in Sierra Leone from which the species has been reported: 1. Loma Mountains; 2 . Tingi Hills;

3. Gola Forest; 4. Mokanji Hills.

Peninsula in September 1988, and brought to light the first conclusive evidence of Jentink's duiker, giving credence to earlier reports.

\section{Specimens}

Two hunters produced a total of five horns of adult and juvenile Jentink's duikers, and one tail. The largest pair of horns is black, almost straight with downward-pointing tips, and narrow with an oval rather than triangle crosssection. They measure $215 \mathrm{~mm}$ in length, each base has a circumference of $95 \mathrm{~mm}$ and the lower $35 \mathrm{~mm}$ are conspicuously ridged. Only black hairs are found on the skin between the horns; there is no evidence of a tuft or redbrown hairs. The tail, removed from an adult animal, is grey.

In addition to these specimens, three hunters gave full and accurate descriptions of animals with black-and-grey bodies, standing about $1 \mathrm{~m}$ tall, with a body length of about 1.5 $\mathrm{m}$. In the Krio language of the area the species is called gidi-gidi, or gri-gri, which derives from the French word for grey, and refers to the species's main body colour.

The three hunters reported sightings and kills of Jentink's duiker in the southern part of the Freetown Peninsula where they had been hunting: $1982-1$ kill; $1986-1$ kill; $1987-2$ sightings; 1985 - 5 kills (Figure 1).

\section{Habitat and ecology}

The hill range of Freetown Peninsula is relatively narrow, approximately $37 \mathrm{~km}$ long and $14 \mathrm{~km}$ wide, with peaks reaching $900 \mathrm{~m}$ and a thin coastal strip on the northern, western and southern sides. Freetown (population 450,000) occupies the northern end of the Peninsula and many settlements are found along the road leading east from the capital. On the Peninsula Circular Road, along the west coast, there are some scattered fishing communities 
but there are very few villages on the steep hills of the interior.

The unpopulated interior hills are covered in evergreen forest, which is where Jentink's duikers appear to spend most of the year. Much farming and wood collection occur on the forest edge and during the rainy season, between May and October, the animals come down from the forest at night and feed in the coastal farmlands. The duikers eat shoots of shrubs and young trees in the older 'farmbush' fallow areas. One hunter noted that Jentink's duikers browsed most commonly on Hannoa klaineana and Chlorophora regia.

It appears from these hunters' reports that Jentink's duiker is not as wholly dependent on closed-canopy forest as was generally believed (Kuhn, 1965; Roth and Merz, 1986). Duikers are mainly frugivorous (Dubost, 1984), but in the rainy season forest trees produce few fruits and it is then that the species makes use of forest edges and farm-bush. Unfortunately, on these forays out of the forest the duikers are vulnerable to hunters, who use lamps to spot the duikers' eyeshine, dazzle and then shoot them. Some duikers are also trapped in snares set at the forest-farm edge.

\section{Other populations in Sierra Leone}

With this concrete evidence from the Freetown Peninsula, it is more interesting to consider reports of Jentink's duiker from other areas of the country. The Gola Forest Reserves in eastern Sierra Leone constitute the only large tract of lowland forest in the country. Local hunters have described the animals (Davies, 1987), and there is a Mende tribal name, kaikulowuli, which means 'squirrel duiker' and refers to the animal's grizzled pelage. Mr S. MusaJambawai (Conservation Society of Sierra Leone) reported shooting one in Gola North in 1959, and F. Sitter (animal dealer) reports having seen skins in Golahun (near Gola East) in the 1970s. More recently, a forest ranger reported seeing a Jentink's duiker that was trapped on the edge of Gola North last year.

North of the Golas, in terrain more like that of the Freetown Peninsula hills, Sitter reports

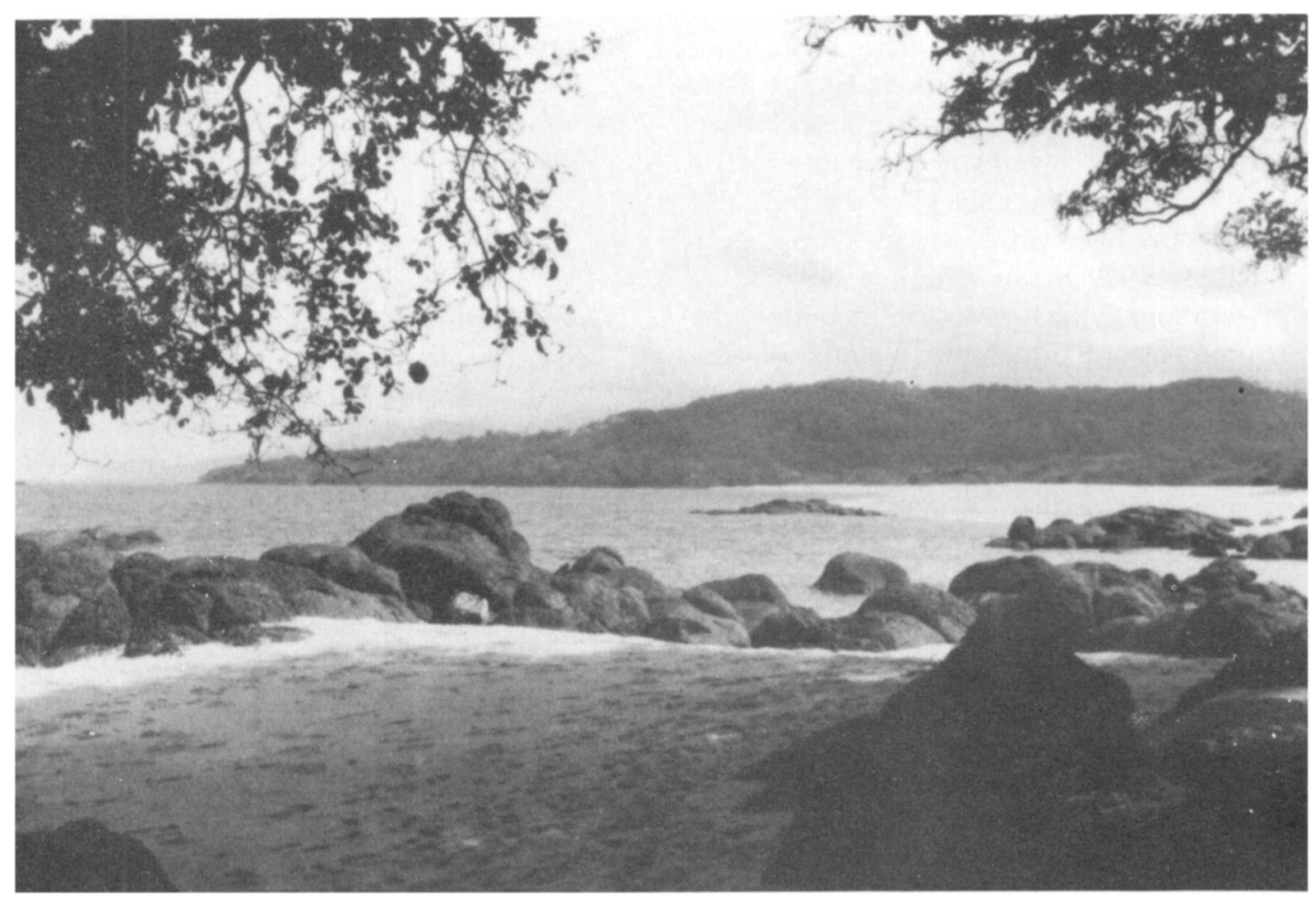

South-western part of the Freetown Peninsula from the beach (B. Birkenhäger). 
seeing skins and horns in the towns of Yifin and Kruto at the base of the Loma Mountains and a skin in the nearby Tingi Hills. He also reports animals in the Mokanji Hills, an area that has been devastated by open-cast mining.

\section{Conservation}

The known range of Jentink's duiker has been moved considerably further west following this report, but the species remains very rare. Without more details on the species's ecology, it is not possible to determine what limits population size and distribution, but the above description clearly indicates that animals are being killed. It is therefore of great importance that surveys be carried out to ascertain where the species still occurs in Sierra Leone, at what approximate densities, and to judge what pressure each population faces from hunters. Such surveys are planned for the end of the year by V. Wilson (Chipangali Wildlife Trust, Bulawayo).

In the Freetown Peninsula there is already enough information to show that urgent conservation action is needed. The agricultural potential of the hills is low due to shallow soils, low soil fertility and steep relief. Therefore, forest cover is the most appropriate use of the land, especially since the hills also supply water to Freetown (two reservoirs).

Phillipson (1978), in a report on wildlife conservation, which was ratified by the Government of Sierra Leone, pointed out the need for wildlife conservation in the Freetown Peninsula. The new evidence of Jentink's duiker reinforces his recommendations. Other rare mammals in these forests include diana monkeys, black-and-white colobus, chimpanzees and probably leopards.

Wildlife conservation should be integrated with tourism, since a small-scale tourist industry already exists on the Peninsula. Foreign tourists stay in beach hotels, some of which are close to the area where Jentink's duikers have been seen. Organized tours should be encouraged, especially since there are picnic areas near the reservoirs and a poorly kept nature trail, which needs repair. An obvious corollary to any organized tourism is conservation education. Most people are unaware of the rarity of Jentink's duiker and even local hunters claim not to realize that Jentink's duiker is protected by law.

The functions of water protection, wildlife protection, conservation education and tourism should be carried out in the 17,000 ha of forest reserves on the Peninsula, which were originally gazetted for protection purposes. The indiscriminate felling of trees for fuel in these reserves, which results from acute shortages in Freetown and some of the fishing villages, should be replaced by a system of buffer zones on the periphery of the reserved forest, which are managed on a sustainable basis for fuelwood. Such a management system is being applied on a pilot-scheme basis by FAO/UNDP.

This type of integrated management approach would satisfy the demands of several interest groups and so improve the chances for long-term success in the conservation of Jentink's duiker.

\section{References}

Davies, A.G. 1987. The Gola Forest Reserves, Sierra Leone. IUCN, Gland, Switzerland and Cambridge, UK.

Dubost, G. 1984. Comparison of the diets of frugivorous forest ruminants of Gabon. J. Mammal. 65, 298-316.

Jones, T.S. 1960. Notes on the commoner Sierra Leone mammals. Niger. Fld, 31, 4-17.

Kuhn, H.J. 1965. Provisional checklist of Mammals of Liberia. Senikenberg. Biol. 46, 321-340.

Phillipson, J.A. 1978. Wildlife conservation and management in Sierra Leone. Special report to the Ministry of Agriculture, Freetown.

Roth, H.H. and Merz, G. 1986. Vorkommen und relative Haufigkeit von Saugetieren im TaiRegenwald der Elfenbeinkuste. Saugetierkund-liche Mitteilungen, 33, 171-193.

Stanley, W.B. 1928. Game preservation in Sierra Leone. Sierra Leone Stud. 11, 2-15.

Glyn Davies, Gola Project, c/o Conservation Society, P.O. Box 1292, Freetown, Sierra Leone.

Bastian Birkenhäger, c/o P. J. Jongman, Schepenstraat, 28A, $3039 \mathrm{NH}$ Rotterdam, The Netherlands. 